\title{
Rapidan progrediáló csípő osteoarthrosis
}

\author{
Esetismertetés
}

DR. BALOGH ZSÓFIA, DR. BUCSI LÁSZLÓ

\section{ÖSSZEFOGLALÁS}

A rapidan progrediáló csípő osteoarthrosis a csípőt érintő kopásos megbetegedések egyik ritka alfaja, amely az ízület teljes destrukciójához vezethet esetenként kevesebb, mint 6 hónap alatt. Kialakulásának pontos oka nem ismert, kevés esetszám miatt felismerése igen nehéz. Ezen betegek hagyományos várólistára való helyezése a betegség gyors előrehaladása miatt nem előnyös, mivel a kialakuló csonthiány technikailag nehezebb mútétet eredményez. A hasonló radiológiai kép miatt elkülönítése nagyon fontos a szeptikus arthritistől, osteonecrosistól valamint Charcot neuropathia miatt kialakult elváltozásoktól.

\section{Kulcsszavak: $\quad$ Arthralgia; Csípö; Osteoarthritis; Progrediáló betegség;}

Zs. Balogh, L. Bucsi: Rapid progressive osteoarthritis of the hip. Case report

Rapid progressive osteoarthritis of the hip is a very rare subtype of diseases that can cause arthritis in the hip joint. This subtype can cause a rapid destruction of the whole joint, sometimes in less than 6 month. The etiology of this disease in unknown, and because of its rarity the identification is also hard. Putting these patients on the waiting list is not favourable, because the progression can be very rapid, and the resulting bone loss can be severe, so therefore the surgery technically more difficult. Differentiating this disease from other ones, like septic arthritis, osteonecrosis and Charcot neuropathy can be difficult, because radiologically they can look quite similar.

Keywords: $\quad$ Arthralgia-Diagnostic imaging/Etiology/Surgery; Disease progression; Hip - Diagnostic imaging/Surgery; Osteoarthritis, hip - Diagnostic imaging/Surgery; 


\section{BEVEZETÉS}

A rapidan progrediáló csípő osteoarthrosis a csípőt érintő kopásos megbetegedések egyik ritka alfaja, amelyet először Forestier írt le 1957-ben. Jellemzője, hogy az ízület teljes destrukciójához vezethet esetenként akár pár hónap alatt (3).

A betegség kialakulásának oka nem ismert, kevés esetszám miatt felismerése igen nehéz. Nagyon ritkán kerül diagnosztizálásra, ezért prevalenciájáról egzakt adat nem áll rendelkezésre. A betegségben többségében idősebb nőbetegek érintettek, kialakulásakor az átlagéletkor 70 év körül van. Az esetek 80-90\%ában egyoldali megjelenésǔ. A megjelenéskor tapasztalt életkor általában egy évtizeddel magasabb, mint a primer coxarthrosis esetében (3).

Egyes szerzők a korábban elszenvedett traumát kiváltó okként írták le (2). Pathomechanizmusában subchondralis fracturák meglétének tulajdonítanak jelentőséget (1), azonban nem minden ilyen törésnél alakul ki a kórkép. Fukui és munkatársai publikációjukban kapcsolatot véltek felfedezni az invertált acetabulum labrum és a rapidan progrediáló csípő osteoarthritis között. Közleményük szerint az acetabulum labrum inverziója megszakítja a combfej és az acetabulum között lévő szívóerőt. Ez a porcra kifejtődő stresszt növeli, és az ezáltal fellépő subchondralis insuffitientia törésekhez vezet (1).

A rapidan progrediáló csípő osteoarthritis első tünete a fájdalom, amely sokszor igen erős. Éles ellentétben az ekkor elvégzett röntgenvizsgálattal, amelyen sokszor nem látható a kifejezett panaszt magyarázó elváltozás.

Egy kórházunkban kezelt idős nő esetét ismertetjük, amellyel a betegség gyors lefolyását kívántuk demonstrálni. Célunk ezzel az összefoglalóval, valamint esetbemutatással a rapidan progrediáló csípő osteoarthrosis hamarabbi felismerése, a differenciáldiagnózisban előforduló nehézségek elkerülésének elősegítése.

\section{ESETBEMUTATÁS ÉS UTÁNKÖVETÉS}

Egy 83 éves nőbeteg ortopédiai anamnézisében 2015-ben jobb csípő TEP beültetése szerepelt. 2018 nyarán, júniusban jelentkeztek újra panaszai, erős bal csípőtáji fájdalom formájában. Szeptember elején jelent meg kórházunk ortopédiai szakrendelésén operáló orvosánál. Az akkor elkészült röntgenvizsgálaton, a bal oldalon beszúkült ízületi rés látszott, osteophyta képződés nélkül (1. ábra).

A betegnek mútétet ajánlottunk, amelyet elfogadott, így várólistára került. Ugyanazon év novemberében újra jelentkezett panaszai romlása, erős fájdalmak, következményes csökkent mobilitás miatt. Az akkor elkészült röntgenfelvételen a bal combfej csaknem teljes felszívódása volt látható (2. ábra).

A preoperatív kivizsgálást azonnal megkezdtük, majd betegünknél bal oldali TEP beültetést végeztünk, amely szövődménymentesen megtörtént. $\mathrm{Az}$ acetabulumot nem érintette a csontfelszívódás, így nem vált szükségessé csont pótolása, valamint speciális implantátum beültetése (3-4. ábrák).

Mútét utáni mobilizálását osztályunkon megkezdtük, majd a beteg rehabilitációs intézménybe került. A hathetes kontrollvizsgálaton sebe békés volt, fájdalmat nem panaszolt. A 12 hetes kontrollvizsgálatra a beteg panasz nélkül érkezett. A bal csípő felett per primam gyógyult mútéti heg volt látható, gyulladás jele nélkül. $A z$ alsó végtagok között hosszkülönbség nem volt észlelhető. A beteg támbot segítségével jól mobilizált. A bal csípő mozgásai a következők voltak: flexio 0-100 fok, abductio 0-30 fok, adductio 0-20 fok, kirotáció 0-20 fok, berotáció 0-40 fok.

$A z$ elvégzett röntgenvizsgálaton mindkét oldali TEP jó helyzetű volt, lazulásra utaló jelet nem detektáltunk. 


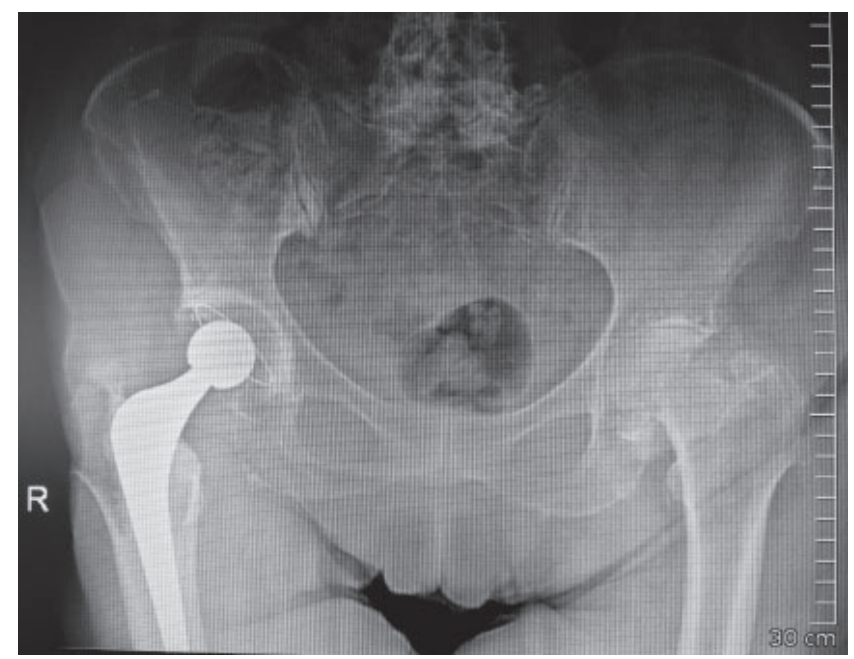

1. ábra

Az első röntgenvizsgálat 2018 szeptemberében

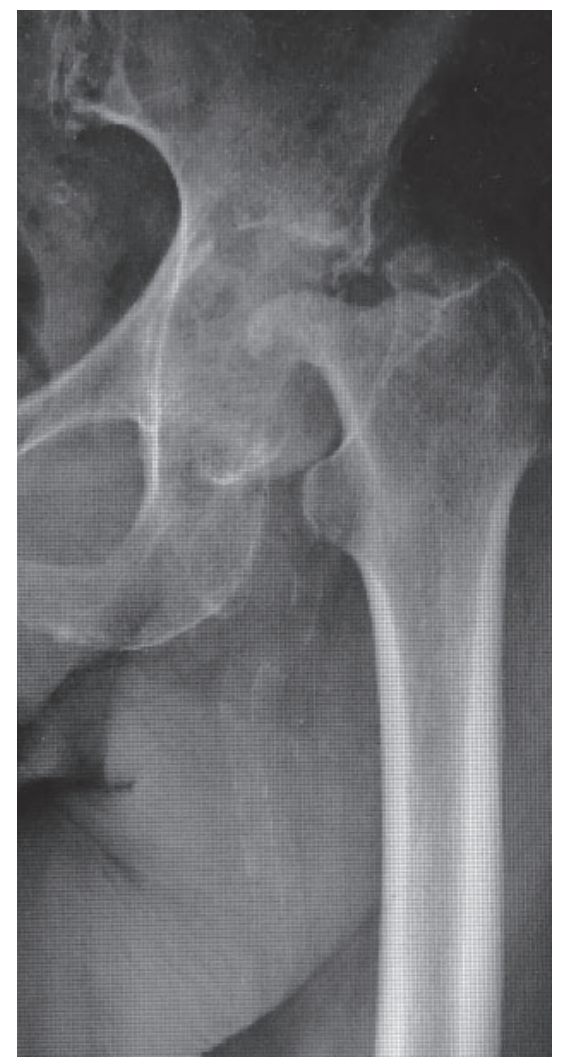

2. ábra

2018 novemberében készült röntgen a bal csípőröl 


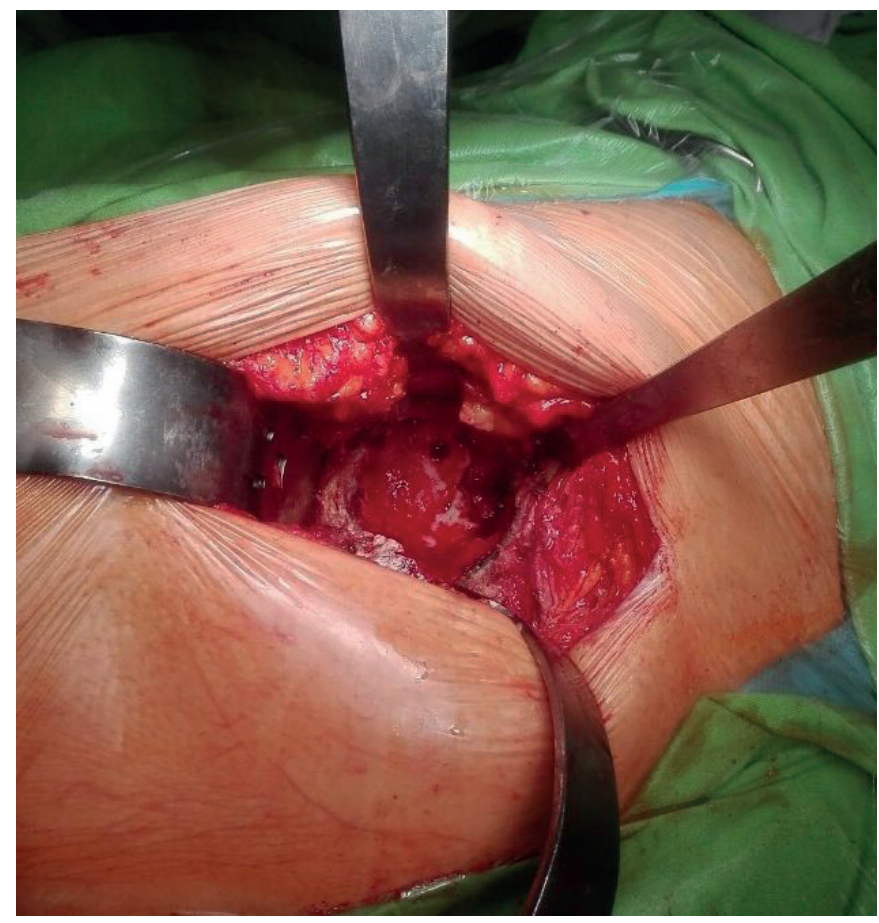

3. ábra

Az acetabulum intraoperativ képe

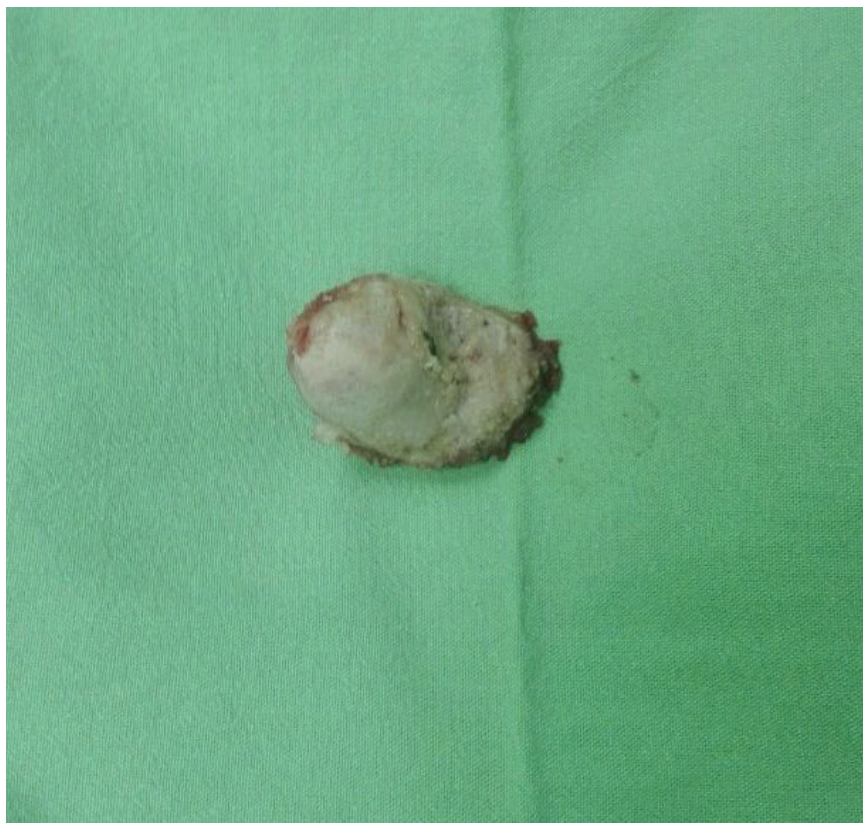

4. ábra

Az eltávolított, csaknem teljesen felszívódott combfej 


\section{MEGBESZÉLÉS}

A fent bemutatott betegség nagyon ritka, felismerése, a diagnózis felállítása a gyors lefolyás miatt igen nehéz. Áttekintve az irodalmat, igen kevés publikáció áll rendelkezésre e témakörben, magyar közleményt nem találtunk.

Lequesne definíciója szerint a betegség diagnózisához a beteg legalább egy éves követése, az elvégzett ismételt röntgenvizsgálatokon az ízületi rés méretének összehasonlítása szükséges. A csontdestrukció rohamos előrehaladása miatt ez a módszer megkésett diagnózishoz vezethet. A korai kórmeghatározáshoz MR vizsgálat elvégzése ajánlott, azonban ennek állami keretek között való elvégzése a kis kapacitás, a vizsgálatra való hosszú várakozás, valamint a betegség rapid előrehaladása miatt nehézkes. A kialakuló csonthiány, nemcsak a combfejet, de az acetabulumot is érintheti. Amennyiben ez a hiány kiterjedt, komoly mútéti nehézségeket okozhat. Csontpótlás válhat szükségessé, valamint a várható vérveszteség is fokozódhat (4). Mindezek miatt a mútéti idő megnövekedhet, ezzel a beteg transzfúziós igénye szintén nőhet, amely nemcsak plusz költséget ró az ellátóra, de szövődmény kialakulásának lehetőségét is emelheti, valamint a beteg késői túlélési esélyeit is ronthatja. Ezért e betegek hagyományos várólistára való helyezése, a mútét bizonytalan ideig való halasztása nem javasolt.

A fent felsorolt okok miatt fontos, hogy ha egy beteg erős csípő fájdalmakat panaszol, és az elvégzett röntgenvizsgálaton nem látunk erre adekvát okot, akkor gondoljunk a rapidan progrediáló osteoarthrosisra is, mint kiváltó okra.

\section{IRODALOM}

1. Bhimani R., Singh P., Bhimani F.: Rapidly progressive hip disease. A rare entity in Korean population. Int. J. Surg. Case Rep. 2018. 53: 486-489. https://doi.org/10.1016/i.ijscr.2018.11.055

2. Flemming D. J., Gustas-French C. N.: Rapidly progressive osteoarthritis: a review of the clinical and radiologic presentation. Curr. Rheumatol. Rep. 2017. 19. (7). 42. https://doi.org/10.1007/s11926-017-0665-5

3. Mavrogenis A. F., Flevas D. A., Panagopoulos G. N., Megaloikonomos P., Igoumenou V., Vottis C., Sakellariou V., Kontogeorgakos V.: Rapid destructive arthritis of the hip revisited. Eur. J. Orthop. Surg. Traumatol. 2015. 25. (7): 11151120. https://doi.org/10.1007/s00590-015-1676-4

4. Zazgyva A, Gurzu S, Gergely I, Jung I, Roman CO, Pop TS. Clinico-radiological diagnosis and grading of rapidly progressive osteoarthritis of the hip. Medicine (Baltimore). 2017. 96. (12): e6395. https://doi.org/10.1097/MD.0000000000006395

\section{Dr. Balogh Zsófia}

Fejér Megyei Szent György Egyetemi Oktató Kórház

Mozgásszervi Sebészeti Centrum, Ortopédiai osztály

8000 Székesfehérvár, Seregélyesi út 3.

E-mail: dr.zsofia.balogh@gmail.com

Mobil: +36 205775281 
